\title{
Interaction between Vetiver Grass Roots and Completely Decomposed Volcanic Tuff under Rainfall Infiltration Conditions
}

\author{
Ling Xu $\mathbb{D}^{1},{ }^{1}$ Chongyang Gao, ${ }^{1}$ and Dongdong Yan $^{2}$ \\ ${ }^{1}$ Department of Civil Engineering, School of Human Settlements and Civil Engineering, Xian Jiaotong University, Xian 710049, China \\ ${ }^{2}$ Department of Geotechnical and Tunnel Engineering, School of Highway, Chang'an University, Xian 710064, China
}

Correspondence should be addressed to Ling Xu; suyu820@163.com

Received 28 January 2018; Revised 30 March 2018; Accepted 8 April 2018; Published 14 May 2018

Academic Editor: Liangping Li

Copyright (C) 2018 Ling Xu et al. This is an open access article distributed under the Creative Commons Attribution License, which permits unrestricted use, distribution, and reproduction in any medium, provided the original work is properly cited.

\begin{abstract}
The important role of vetiver grass roots in preventing water erosion and mass movement has been well recognized, though the detailed influence of the grass roots on soil has not been addressed. Through planting vetiver grass at the Kadoorie Farm in Hong Kong and leaving it to grow without artificial maintenance, the paper studies the influence of vetiver grass roots on soil properties and slope stability. Under the natural conditions of Hong Kong, growth of the vetiver grass roots can reach $1.1 \mathrm{~m}$ depth after one and a half year from planting. The percentage of grain size which is less than $0.075 \mathrm{~mm}$ in rooted soil is more than that of the nonrooted soil. Vetiver grass roots can reduce soil erosion by locking the finer grain. The rooted soil of high finer grain content has a relatively small permeability. As a result, the increase in water content is therefore smaller than that of nonrooted soil in the same rainfall conditions. Shear box test reveals that the vetiver grass roots significantly increased the peak cohesion of the soil from $9.3 \mathrm{kPa}$ to $18.9 \mathrm{kPa}$. The combined effects of grass roots on hydrological responses and shearing strength significantly stabilize the slope in local rainfall condition.
\end{abstract}

\section{Introduction}

The use of vetiver grass for various applications in erosion and sediment control was developed by the World Bank for soil and water conservation in India in the 1980s [1]. Many literatures reviewed or studied the characteristics of vetiver grass and its application in preventing soil erosion and mass movement [2-9]. Rainfall infiltration is a key factor to control slope stability $[10,11]$. In all, the effects of vetiver grass roots on erosion control and mass movement can be summarized as follows: (1) preventing surface erosion through the soilbinding properties of roots, (2) reducing effects of splash erosion through rainfall interception of vegetation canopy, (3) reducing the incidence of shallow slope instability through the anchoring properties of roots, (4) channeling run-off to alter slope hydrology, and (5) providing support to the base of the slope and trapping material moving down the slope.

Hong Kong is a small place and is densely populated; urban development has been carried out over the decades, which has led to enormous pressures on the fragile mountain environment. Most of Hong Kong's crucial rain is brought by the monsoon, which falls in just a few weeks between May and September (Figure 1). In combination with the monsoon climate, very steep slopes, and inherently weak geological conditions, these factors make Hong Kong highly susceptible to erosion and landslides [12-17]. So, vetiver grass, as an important species used for soil bioengineering, is selected in this research to deal with erosion problems and shallow landslides in Hong Kong (Figure 2).

The paper focused on the influence of vetiver grass roots on physical and mechanical properties of soil which has not been addressed, though the important role of vetiver grass roots in preventing water erosion and mass movement has been recognized in recent years. Because the majority of published literatures are based on practical experience or not under such local nature conditions of Hong Kong, there is still a clear need for scientific research concerning the influence of vetiver grass roots on physical and mechanical 


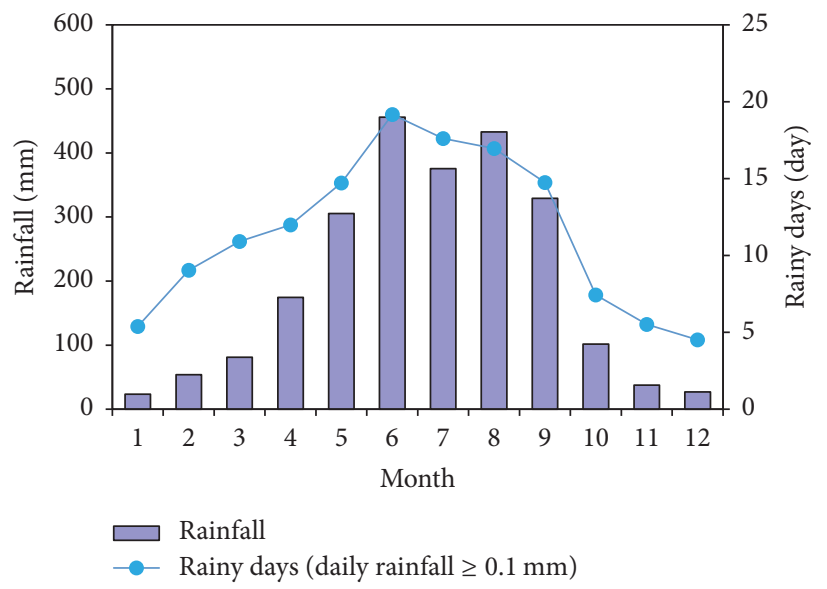

FIGURE 1: The monthly average of rainfall and rainfall days recorded by the observatory in 1981-2010.

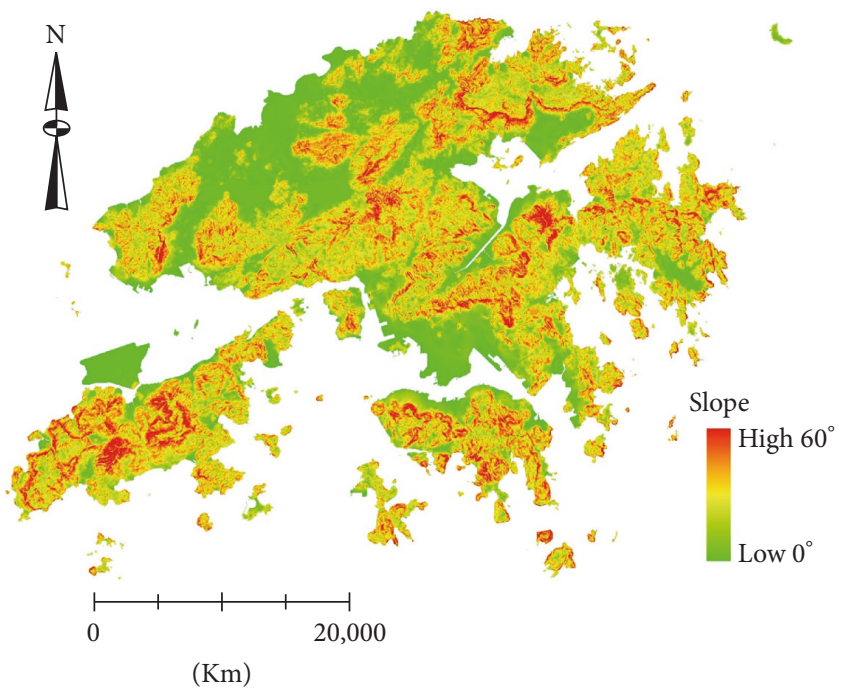

FIgURE 2: The site and DEM of Hong Kong.

prosperities. In this study, the in situ water content was tested by moisture probe in field. Tests consisting of water content, soil density, grain-size distribution, permeability, and direct shearing were carried out in the laboratory. All items were conducted on rooted and nonrooted soil, respectively.

\section{Planting Site and Vetiver Grass Growth}

Vetiver grass used in this research has been planted at the Kadoorie Farm of Hong Kong in June. Vetiver grass was planted at spacing of $1 \mathrm{~m}$ on a steep slope surface (Figure 3 ). The slope is $10 \mathrm{~m}$ long and has a maximum height of about $10 \mathrm{~m}$. The slope was formed to an angle of $60^{\circ}$ by cutting into completely decomposed volcanic tuff.

In order to test its survivability, no water and nutrients were artificially given to the grass during its growth. In 3 months after planting, the grass had grown up to $1.0 \mathrm{~m}$ high (Figure 4(a)). Figure 4(b) shows a typical grass roots system. The maximum root depth is $1.1 \mathrm{~m}$ and the root diameter ranges from $0.05 \mathrm{~mm}$ to $4 \mathrm{~mm}$. Main roots were mostly found within the $25 \mathrm{~cm}$ below the ground surface, and for the depth greater than $25 \mathrm{~cm}$ from the surface, fibrous roots were mostly found.

Figure 5 shows the development of the grass stem length against time. At the time of field sampling and testing in January, the grass had grown to about $1.8 \mathrm{~m}$ tall in a very healthy condition despite the fact that it had been exposed to heavy rain in the summer and a very dry winter.

\section{Field and Laboratory Test Results}

3.1. Physical Properties. Herein, physical properties include water content, soil density, grain-size distribution, and permeability. All these items were conducted on both rooted soil and nonrooted soil to explore the influences of vetiver grass roots on soil's physical properties.

Water Content. Firstly, soil water content was studied in field on nonrooted and rooted soil. The ML2X moisture probe and data logger produced by detaT company in UK were used 


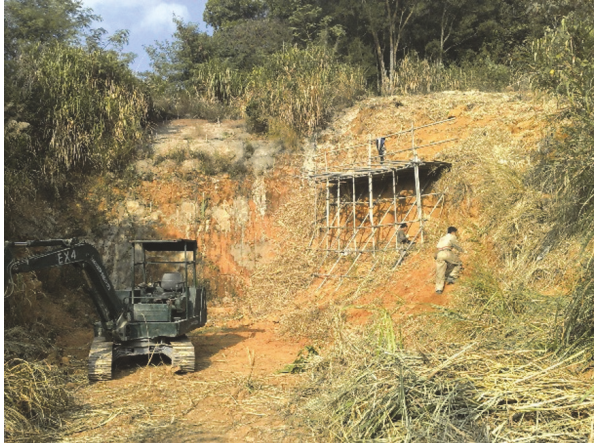

(a)

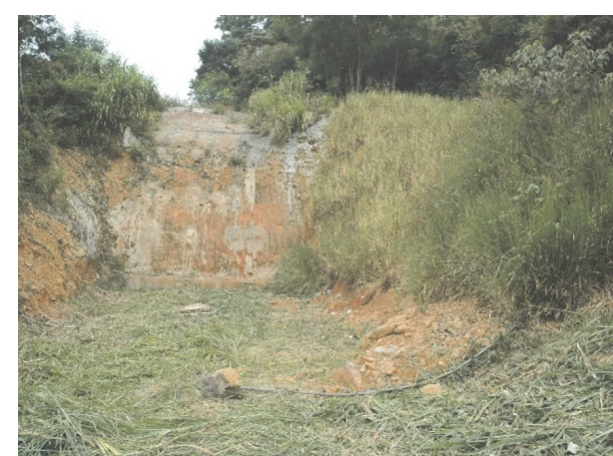

(b)

FIGURE 3: Panorama of research site (a) before grass planting and (b) during field testing.

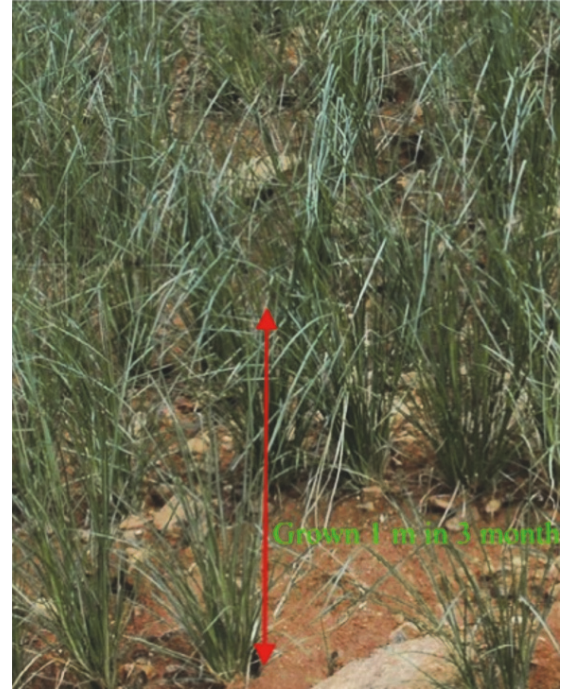

(a)

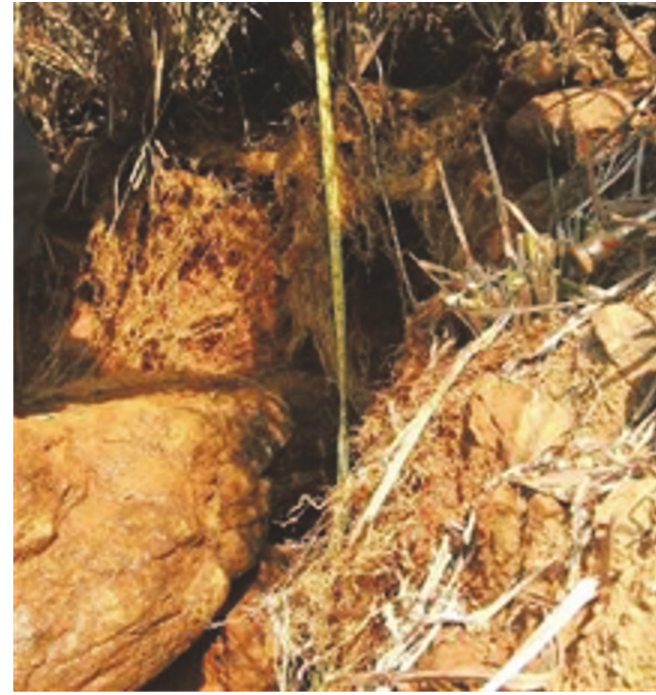

(b)

Figure 4: (a) Vetiver stem growth in 3 months after planting. (b) Typical grass root system.

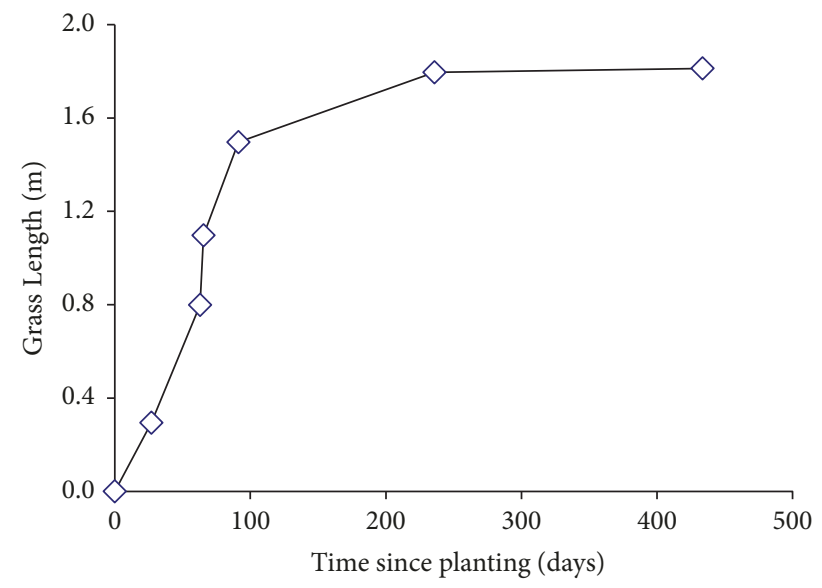

FIGURE 5: The development of the grass stems length against time.

in this test. The selected testing locations and the measured output voltage value are shown in Figure 6. According to the calibration curves of measured voltage and water content, the mass water content was obtained as shown in Table 1. Soil water content was also tested in laboratory. The soil tested was taken from the sample surface when the sample box was opened in laboratory. The water content was measured by drying method. The results are shown in Table 2.

From the results of the in situ and laboratory water content shown in Table 3, it is observed that vetiver grass roots increased the average soil water content by about $11.63 \%$ in field. The increase scale in laboratory testing is $8.26 \%$. It is less than that obtained in field and may be because of the difference of two types of samples in water loss.

Soil Density. The soil used for density testing was taken from the block sample surface when opening the box in laboratory. Ring-knife method was used in this test. Inner diameter of the ring-knife is $61.8 \mathrm{~mm}$ and height is $20 \mathrm{~mm}$. Test results are shown in Table 4 . It can be found that the average density of soil with roots is $1.81 \mathrm{~g} / \mathrm{cm}^{3}$, which is higher than that of the soil without roots, $1.67 \mathrm{~g} / \mathrm{cm}^{3}$. Using the laboratory water 
TABLE 1: In situ measured voltage of moisture probe and corresponding water content.

\begin{tabular}{|c|c|c|c|c|}
\hline Sample types & Voltage tested (mv) & Water content $(\%)$ & Voltage tested (mv) & Water content (\%) \\
\hline \multirow{13}{*}{ Rooted soil tested in field } & 454.00 & 15.10 & 580.00 & 17.73 \\
\hline & 453.00 & 15.08 & 282.00 & 11.50 \\
\hline & 453.00 & 15.08 & 236.00 & 10.54 \\
\hline & 453.00 & 15.08 & 647.00 & 19.13 \\
\hline & 458.00 & 15.18 & 394.00 & 13.84 \\
\hline & 563.00 & 17.37 & 436.00 & 14.72 \\
\hline & 453.00 & 15.08 & 402.00 & 14.01 \\
\hline & 438.00 & 14.76 & 472.00 & 15.47 \\
\hline & 572.00 & 17.56 & 433.00 & 14.66 \\
\hline & 452.00 & 15.05 & 339.00 & 12.69 \\
\hline & 491.00 & 15.87 & 345.00 & 12.82 \\
\hline & 481.00 & 15.66 & 336.00 & 12.63 \\
\hline & 597.00 & 18.08 & 316.00 & 12.21 \\
\hline \multirow{4}{*}{ Nonrooted soil tested in field } & 294.00 & 11.75 & 375.00 & 13.45 \\
\hline & 472.00 & 15.47 & 385.00 & 13.65 \\
\hline & 397.00 & 13.90 & 321.00 & 12.32 \\
\hline & 341.00 & 12.73 & & \\
\hline
\end{tabular}

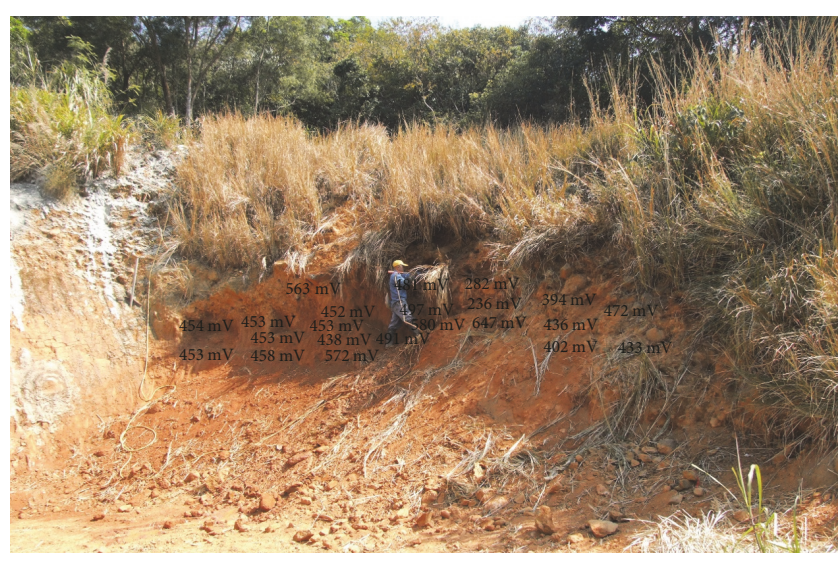

(a) Measured locations in the area in which vetiver was planted

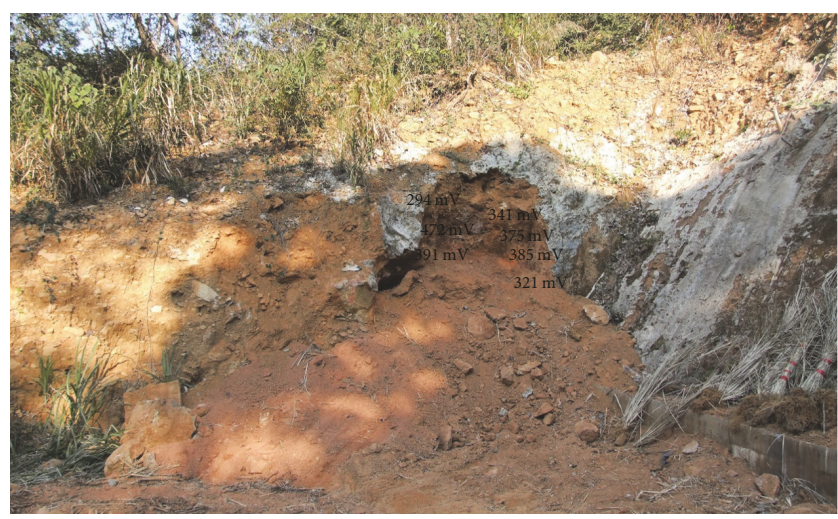

(b) Measured locations in the area in which vetiver was not planted

FIGURE 6: In situ water content locations and corresponding voltage value.
TABLE 2: Laboratory water content on block samples.

\begin{tabular}{lc}
\hline Sample number & $\begin{array}{c}\text { Laboratory water content taken from } \\
\text { sample surface (\%) }\end{array}$ \\
\hline Rootedsample_01 & 21 \\
Rootedsample_02 & 17 \\
Rootedsample_03 & 18 \\
Rootedsample_04 & 21 \\
Rootedsample_05 & 21 \\
Nonrooted sample_01 & 17 \\
Nonrooted sample_02 & 23 \\
Nonrooted sample_03 & 17 \\
\hline
\end{tabular}

content in Table 3, the dry density of soil was calculated in Table 4 . The dry density of rooted soil is $1.51 \mathrm{~g} / \mathrm{cm}^{3}$, about $7 \%$ higher than $1.41 \mathrm{~g} / \mathrm{cm}^{3}$ of the nonrooted soil.

Grain-Size Distribution. Grain-size distribution of rooted and nonrooted soils has traditionally been tested combined by sieving and hydrometer methods in laboratory. The results of grain-size distribution are tabulated in Table 5. Figure 7 shows the average grain size distribution of the soil samples with and without roots. It is observed that the percentage of grain size of $0.075 \sim 0.005 \mathrm{~mm}$ and less than $0.005 \mathrm{~mm}$ in rooted soil is higher than that in the nonrooted soil by $18.2 \%$ and $39.1 \%$, respectively. It indicates that vetiver grass roots can reduce soil erosion by locking the finer grain in soil. 
TABLE 3: In situ and laboratory water content of soil samples.

\begin{tabular}{lccc}
\hline & Soil without roots & Soil with roots & Increase in percentage \\
\hline $\begin{array}{l}\text { Average in situ water content } \\
\begin{array}{l}\text { Average laboratory water content taken } \\
\text { from sample surface }\end{array}\end{array}$ & $13.33 \%$ & $14.88 \%$ & $11.63 \%$ \\
\hline
\end{tabular}

TABLE 4: Laboratory soil density and calculated dry density.

\begin{tabular}{lccc}
\hline Sample number & Laboratory soil density (\%) & $\begin{array}{c}\text { Average natural soil } \\
\text { density }\left(\mathrm{g} / \mathrm{cm}^{3}\right)\end{array}$ & $\begin{array}{c}\text { Calculated dry density } \\
\left(\mathrm{g} / \mathrm{cm}^{3}\right)\end{array}$ \\
\hline Rootedsample_1 & 1.81 & 1.81 & 1.51 \\
Rootedsample_2 & 1.85 & \\
Rootedsample_3 & 1.86 & \\
Rootedsample_4 & 1.79 & \\
Rootedsample_5 & 1.74 & 1.67 \\
\hline Nonrooted sample_1 & 1.70 & \\
Nonrooted sample_2 & 1.66 & 1.41 \\
Nonrooted sample_3 & 1.66 & \\
\hline
\end{tabular}

TABLE 5: Grain-size distribution of different samples.

\begin{tabular}{|c|c|c|c|c|c|c|c|}
\hline \multirow[t]{2}{*}{ Sample number } & \multicolumn{7}{|c|}{$\begin{array}{c}\text { Gain } \\
\text { size }(\mathrm{mm})\end{array}$} \\
\hline & $10 \sim 5$ & $5 \sim 2$ & $2 \sim 0.5$ & $0.5 \sim 0.25$ & $0.25 \sim 0.075$ & $0.075 \sim 0.005$ & $<0.005$ \\
\hline Nonrooted sample_1 & 2.7 & 32.7 & 12.8 & 1.9 & 20.7 & 19.7 & 9.5 \\
\hline Nonrooted sample_2 & 3.7 & 38.2 & 12.5 & 2 & 16.1 & 17.2 & 10.3 \\
\hline Nonrooted sample_3 & 7.4 & 25.7 & 5.3 & 0.9 & 10.9 & 25.9 & 23.9 \\
\hline Rooted sample_1 & 2.2 & 36.1 & 8.9 & 1.2 & 10.5 & 21 & 20.1 \\
\hline Rooted sample_2 & 2 & 25.6 & 10.6 & 1.5 & 15.8 & 26.1 & 18.4 \\
\hline RootedSample_3 & 1.1 & 22.2 & 8.1 & 1.1 & 13.3 & 30.7 & 23.5 \\
\hline RootedSample_4 & 3.6 & 26.3 & 10 & 1.7 & 13.4 & 25.4 & 19.6 \\
\hline RootedSample_5 & 2.7 & 37.8 & 7.6 & 1.1 & 10.6 & 20.5 & 19.7 \\
\hline
\end{tabular}

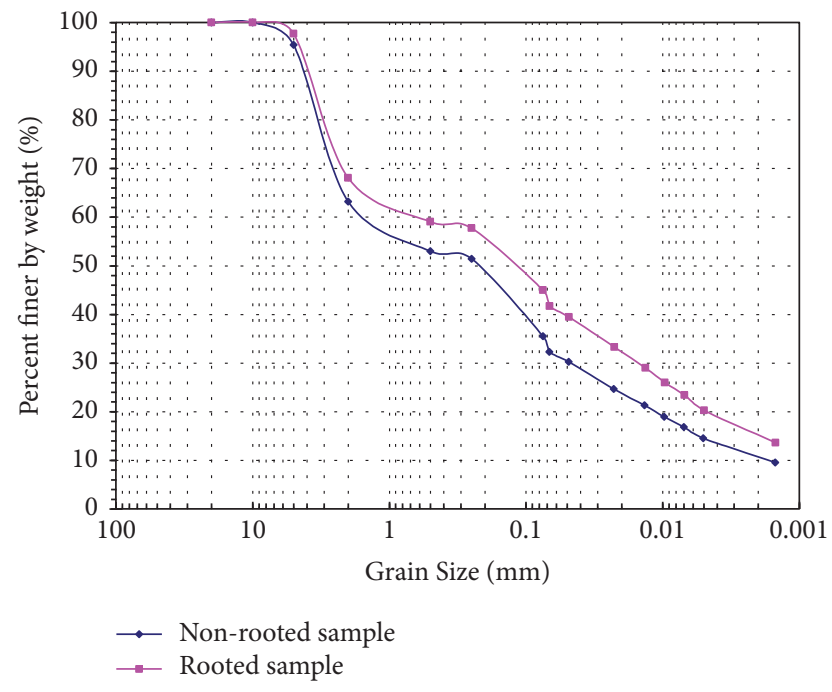

FIGURE 7: Average grain-size distribution of rooted and nonrooted properties.
TABle 6: Densities and moisture content of the soil samples.

\begin{tabular}{lccc}
\hline Sample & $\begin{array}{c}\text { Moisture } \\
\text { content }\end{array}$ & $\begin{array}{c}\text { Moist density } \\
\left(\mathrm{kg} / \mathrm{m}^{3}\right)\end{array}$ & $\begin{array}{c}\text { Dry density } \\
\left(\mathrm{kg} / \mathrm{m}^{3}\right)\end{array}$ \\
\hline $\begin{array}{l}\text { Rooted soil } \\
\begin{array}{l}\text { Nonrooted } \\
\text { soil }\end{array}\end{array}$ & $14.9 \%$ & 1800 & 1500 \\
\hline
\end{tabular}

\subsection{Mechanical Properties}

Shear Box Test Results. Eight samples, each of dimensions $600 \mathrm{~mm} \times 600 \mathrm{~mm} \times 600 \mathrm{~mm}$, were retrieved at location shown in Figure 3. Five samples were matrix of soil containing vetiver grass roots, whereas the remaining three were "bare" soil.

The soil was identified to be completely decomposed tuff. The densities and moisture content were tabulated in Table 6. Furthermore, the particle-size distribution of each sample was determined by taking samples, and the results are 
TABLE 7: Results of large-scale direct shear test.

\begin{tabular}{|c|c|c|c|c|c|c|c|}
\hline \multirow[b]{2}{*}{ Sample number } & \multirow{2}{*}{$\begin{array}{c}\text { Designed } \\
\text { normal } \\
\text { stress } / \mathrm{kPa}\end{array}$} & \multirow[b]{2}{*}{ Displacement $/ \mathrm{mm}$} & \multicolumn{2}{|l|}{ eak state } & \multicolumn{2}{|c|}{ Residual state } & \multirow[b]{2}{*}{ Root area ratio } \\
\hline & & & $\begin{array}{c}\text { Normal } \\
\text { stress/kPa }\end{array}$ & $\begin{array}{c}\text { Shear } \\
\text { stress } / \mathrm{kPa}\end{array}$ & $\begin{array}{c}\text { Normal } \\
\text { stress } / \mathrm{kPa}\end{array}$ & $\begin{array}{c}\text { Shear } \\
\text { stress } / \mathrm{kPa}\end{array}$ & \\
\hline Rooted_1 & 20 & 16 & 22.4 & 32.2 & 24.5 & 19.8 & $1.98 \%$ \\
\hline Rooted_2 & 40 & 18 & 51.3 & 39.5 & 42.9 & 25.4 & $0.88 \%$ \\
\hline Rooted_3 & 60 & 32 & 71.5 & 46.6 & 67.5 & 41 & $1.60 \%$ \\
\hline Rooted_4 & 80 & 22 & 82.9 & 54.4 & 84.6 & 41.4 & $2.45 \%$ \\
\hline Rooted_5 & 120 & 16 & 124.2 & 76.1 & 128.4 & 62.2 & $2.11 \%$ \\
\hline Nonrooted_1 & 10 & 15 & 10.7 & 14 & 9.6 & 10.4 & - - \\
\hline Nonrooted_2 & 80 & 29 & 80 & 45.5 & 79 & 34 & 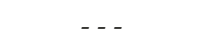 \\
\hline Nonrooted_3 & 120 & 36 & 120 & 63 & 120.3 & 54 & - - - \\
\hline
\end{tabular}

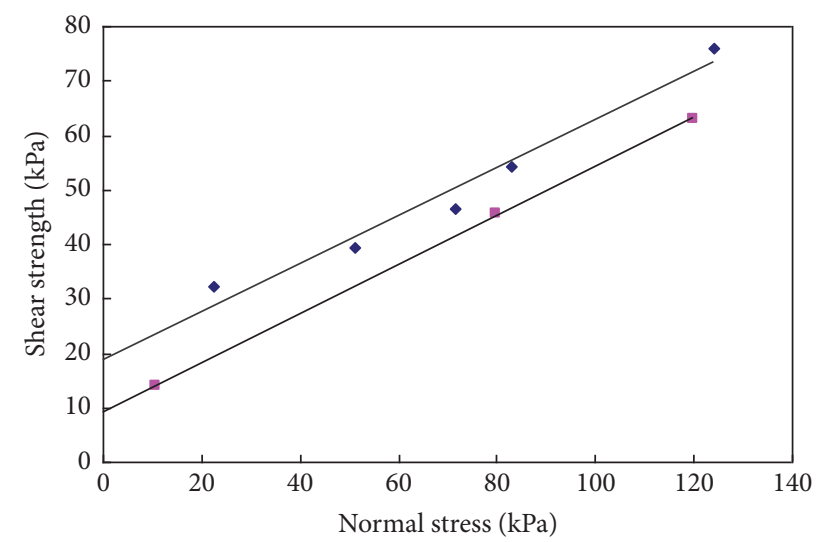

- Rooted samples

- Non-rooted samples

_ Linear fitting line

FIGURE 8: Peak shear strength against normal stress of rooted and nonrooted sample.

depicted in Figure 7. The soil is rather fine with some gravel. The coefficient of uniformity is approximately 5 .

The shear strength obtained is plotted on the $y$-axis with the corresponding normal stress on the $x$-axis. Based on the test results (Table 7), the soil cohesion and frictional angle were obtained (Figures 8 and 9).

As shown in Figure 8, the peak cohesion of rooted soil is $18.9 \mathrm{kPa}$ and the nonrooted soil is $9.3 \mathrm{kPa}$. Vetiver grass roots increased the cohesion by $103 \%$ in this study. The peak friction angles of rooted and nonrooted soils are nearly the same, which are $23.7^{\circ}$ and $24.2^{\circ}$, respectively. The results of residual strength are shown in Figure 9. The residual cohesions of the rooted and nonrooted soils are $8.7 \mathrm{kPa}$ and $5.8 \mathrm{kPa}$ and their corresponding friction angles are $23.1^{\circ}$ and $21.2^{\circ}$.

3.3. Application to Slope Safety. Vetiver grass was used to stabilize the slope. The effect of roots on slope stability is therefore analysed here. As revealed by shearing box testing,

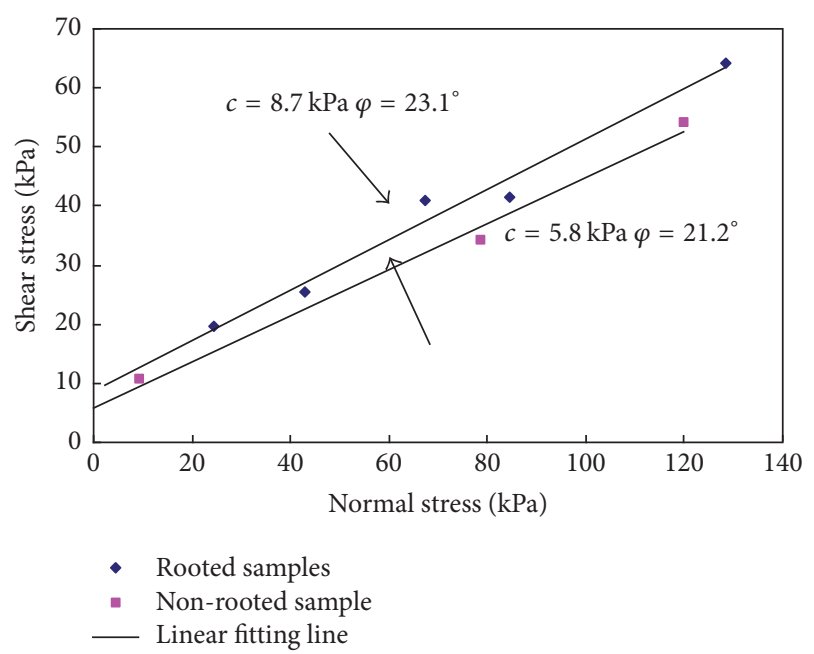

FIGURE 9: Residual shear strength against normal stress of rooted and nonrooted sample.

the grass roots can increase the soil strength. On the other hand, vetiver grass also changed the soil permeability. Finer particles were well reserved in the rooted soil in case of rainfall conditions. This will certainly influence the soil water characteristic curve (SWCC). In this study, the SWCC is evaluated using the soil's particle-size distribution. Soil permeability function is generated for rooted and nonrooted soils. As a result, the soil water contents in slope under the same rainfall conditions are different. The slope stability will therefore be different for rooted soil and nonrooted soil.

A slope is selected in this study. The slope angle is $45^{\circ}$. This is mainly because the $45^{\circ}$ slope is mostly distributed in Hong Kong (Figure 2). The vetiver grass rooted soil is $3 \mathrm{~m}$ deep in vertical direction. The particle-size distribution of rooted and nonrooted soils as shown in Figure 7 is adopted to evaluate SWCC (Figure 10) for grass slope and nongrass slope, respectively. The soil strength as presented in Figure 8 is adopted for the rooted and nonrooted soils. The rainfall intensity of $7.62 \times 10^{-7} \mathrm{~m} / \mathrm{s}$ was used in the model. The preset 


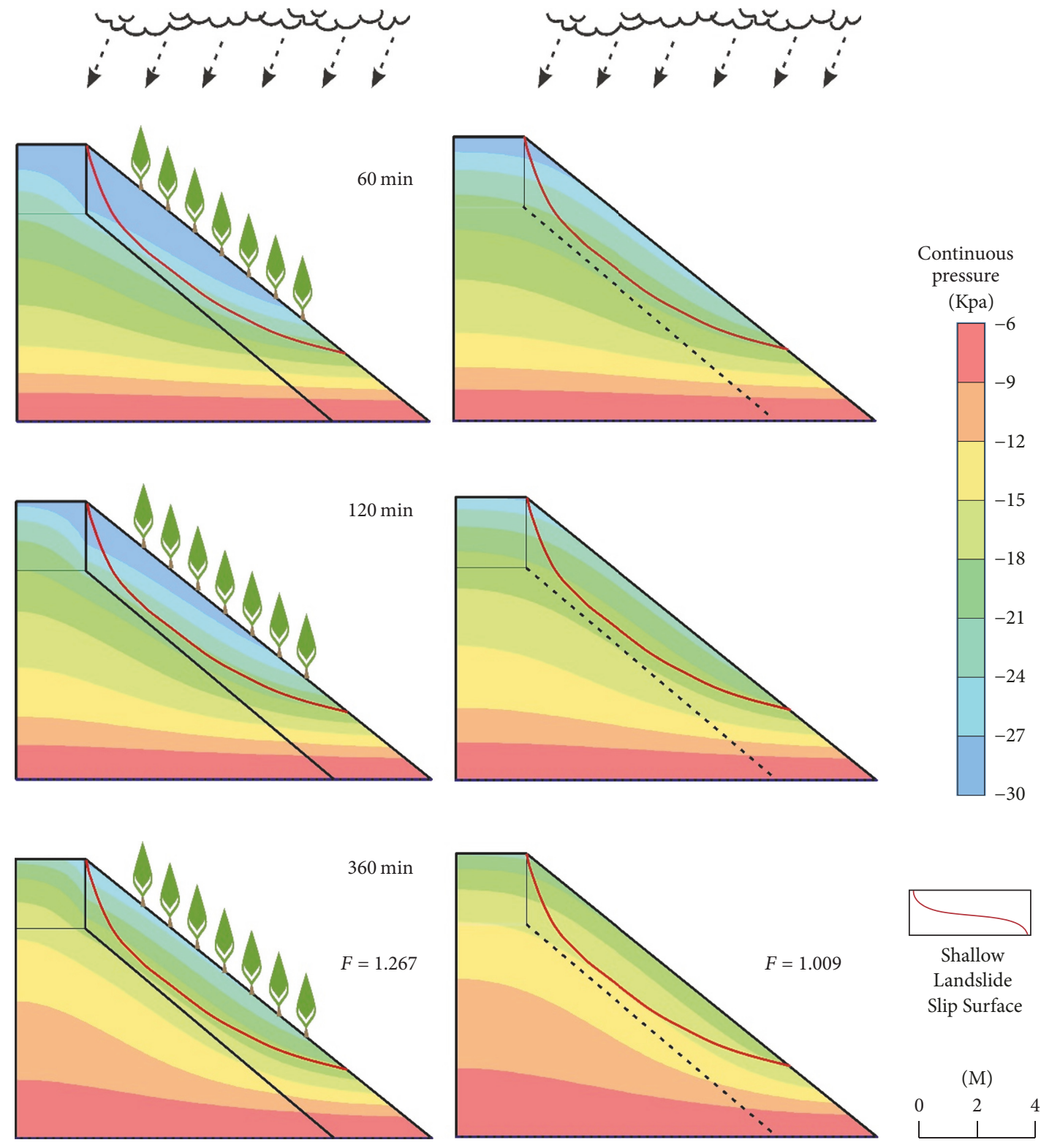

FIGURE 10: Hydrological responses to rainfall and slope stability for nonrooted and rooted slopes.

slip surface was defined in the slope to constitute the base of the comparison between nonrooted and rooted slopes.

Figure 10 shows the results of rooted and nonrooted slopes under rainfall conditions. The rainfall intensity used in this study is calculated from the monthly average of rainfall and rainfall days recorded by the observatory in 1981-2010 (Figure 1). It was found that the rainfall firstly infiltrated into the nonrooted slope is quicker than the rooted slope. It causes the soil in the nonrooted slope to be higher in water content than the rooted slope. The metric suction was evolved in the slope stability analysis. With increasing the soil water content, the soil strengths decrease. The grass root can enhance the soil strength. In this model, the peak strength for nonrooted and rooted soil was adopted in the slope. The data results clearly show that the grass root can increase the slope's stability.

\section{Conclusions}

This study highlights the influence of vetiver grass on soil properties and associated slope stability. It was firstly found that, under the natural conditions of Hong Kong, growth of the vetiver grass roots can reach $1.1 \mathrm{~m}$ depth after one and a half year from planting. Vetiver grass roots can increase the soil water content and density. The vetiver grass roots can reduce soil erosion by locking the finer grain. Grain-size distribution analysis shows that the percentage of grain size of $0.075 \sim 0.005 \mathrm{~mm}$ and that less than $0.005 \mathrm{~mm}$ in rooted soil is higher than those of nonrooted soil by $18.2 \%$ and $39.1 \%$, respectively.

Shear box test results do show that the vetiver grass roots significantly increased the peak cohesion of completely 
decomposed volcanic tuff by $103 \%$ from $9.3 \mathrm{kPa}$ to $18.9 \mathrm{kPa}$. To evaluate the effect of grass roots on slope stability, a numerical modeling was performed. It illustrates that the grass roots can prevent the rainfall water infiltration by locking the finer grain, which is of benefit for slope stabilizing. It was therefore demonstrated that the combined effects of grass roots on hydrological responses and shearing strength can stabilize the slope.

\section{Conflicts of Interest}

The authors declare that they have no conflicts of interest.

\section{Acknowledgments}

The first author thanks Professor L. G. Tham and A. K. L. Kwong from the Hong Kong University. They funded the first author to work at HKU and joined in the research group of vetiver grass project. The authors thank Hong Min from the Institute of Rock and Soil Mechanics, Chinese Academy of Sciences, who carried out some of the laboratory tests. The financial support of the Research Grants Council, the HKSAR Government (Project no. HKU7138/07E), is acknowledged.

\section{References}

[1] P. N. V. Truong and R. Loch, "Vetiver system for erosion and sediment control," in Proceeding of the 13th International Soil Conservation Organization Conference, 2004.

[2] O. Babalola, S. C. Jimba, O. Maduako, and A. O. Dada, "Use of vetiver grass strips for soil and water conservation in Nigeria," in Proceedings of the Third International Conference on Vetiver and Exhibition: Vetiver and Water, China Agriculture Press, Guangzhou, China, October, 2003.

[3] N. Dudai, E. Putievsky, D. Chaimovitch, and M. Ben-Hur, "Growth management of vetiver (Vetiveria zizanioides) under Mediterranean conditions," Journal of Environmental Management, vol. 81, no. 1, pp. 63-71, 2006.

[4] O. Babalola, S. O. Oshunsanya, and K. Are, "Effects of vetiver grass (Vetiveria nigritana) strips, vetiver grass mulch and an organomineral fertilizer on soil, water and nutrient losses and maize (Zea mays, L) yields," Soil \& Tillage Research, vol. 96, no. 1-2, pp. 6-18, 2007.

[5] S. Donjadee and T. Tingsanchali, "Soil and water conservation on steep slopes by mulching using rice straw and vetiver grass clippings," Agriculture and Natural Resources, vol. 50, no. 1, pp. 75-79, 2016.

[6] E. Gnansounou, C. M. Alves, and J. K. Raman, "Multipleapplications of vetiver grass-a review," International Journal of Environmental Sciences, vol. 2, pp. 125-141, 2017.

[7] C. Ghosh and S. Bhattacharya, "Landslides and erosion control measures by vetiver system," in Disaster Risk Governance in India and Cross Cutting Issues, Disaster Risk Reduction (Methods, Approaches and Practices), I. Pal and R. Shaw, Eds., pp. 387413, Springer Singapore, Singapore, 2018.

[8] H. Liu, L. Yao, C. Lin, X. Wang, W. Xu, and H. Wang, "18-year grass hedge effect on soil water loss and soil productivity on sloping cropland," Soil \& Tillage Research, vol. 177, pp. 12-18, 2018.
[9] J. K. Raman and E. Gnansounou, "A review on bioremediation potential of vetiver grass," in Waste Bioremediation, Energy, Environment, and Sustainability, S. Varjani, E. Gnansounou, B. Gurunathan, D. Pant, and Z. Zakaria, Eds., Singapore, 2018.

[10] M. Zhang, Y. Yin, and B. Huang, "Mechanisms of rainfallinduced landslides in gently inclined red beds in the eastern Sichuan Basin, SW China," Landslides, vol. 12, no. 5, pp. 973983, 2015.

[11] M. Zhang and M. J. McSaveney, "Is air pollution causing landslides in China?" Earth and Planetary Science Letters, vol. 481, pp. 284-289, 2018.

[12] E. W. Brand, "Landslides in Hong Kong," in Proceedings of the Eighth Southeast Asian Geotechnical Conference, 1985.

[13] S. W. C. Au, "Rain-induced slope instability in Hong Kong," Engineering Geology, vol. 51, no. 1, pp. 1-36, 1998.

[14] F. C. Dai, C. F. Lee, J. Li, and Z. W. Xu, "Assessment of landslide susceptibility on the natural terrain of Lantau Island, Hong Kong," Environmental Geology, vol. 40, no. 3, pp. 381-391, 2001.

[15] K. T. Chau, Y. L. Sze, M. K. Fung, W. Y. Wong, E. L. Fong, and L. C. P. Chan, "Landslide hazard analysis for Hong Kong using landslide inventory and GIS," Computers \& Geosciences, vol. 30, no. 4, pp. 429-443, 2004.

[16] K. K. S. Ho, "Managing the uncertainties of natural terrain landslides and extreme rainfall in Hong Kong," in Landslide Science and Practice, pp. 285-302, Springer Berlin Heidelberg, Berlin, Germany, 2013.

[17] L. Gao, L. M. Zhang, and R. W. M. Cheung, "Relationships between natural terrain landslide magnitudes and triggering rainfall based on a large landslide inventory in Hong Kong," Landslides, pp. 1-14, 2017. 

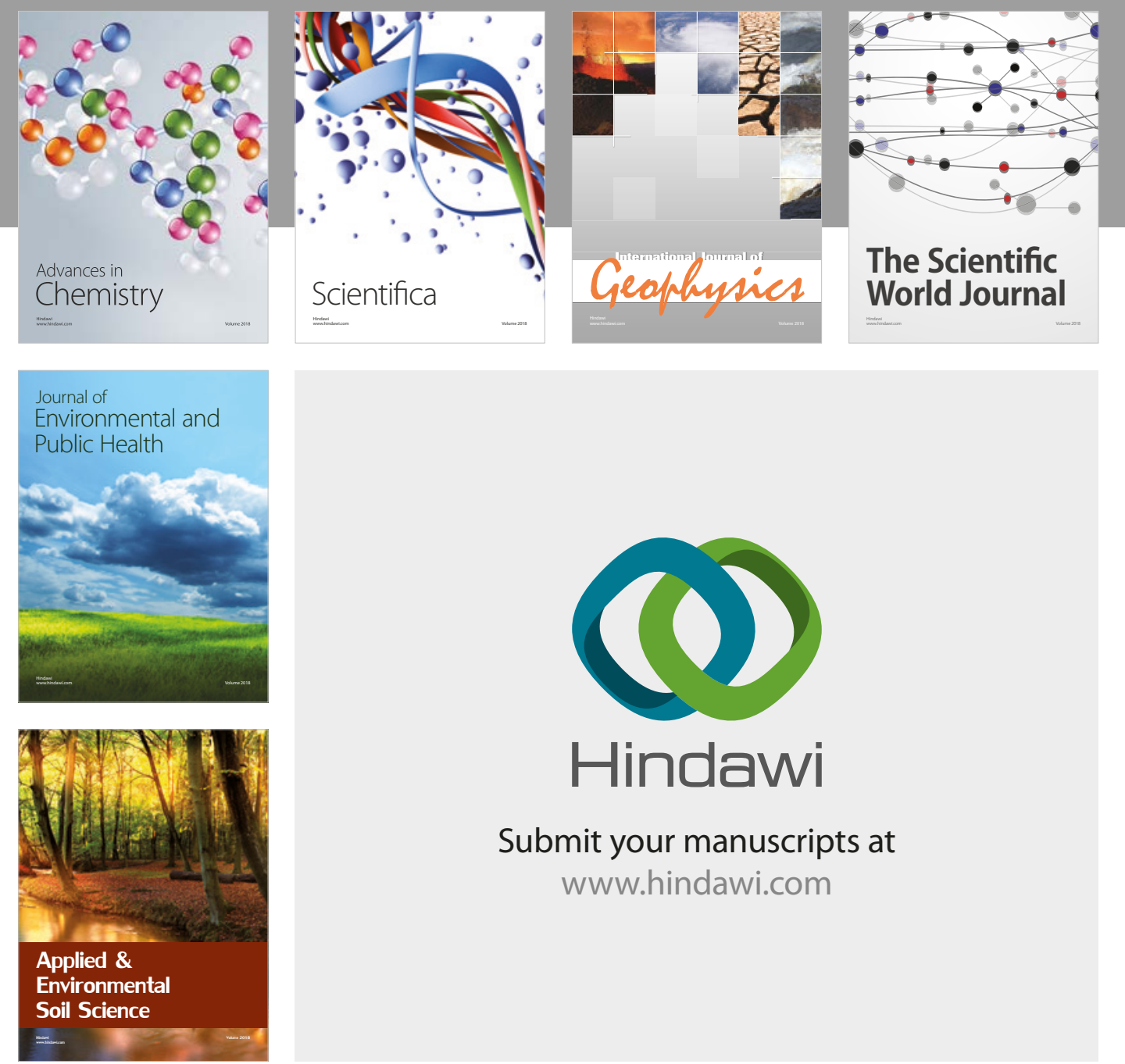

The Scientific

\section{World Journal}
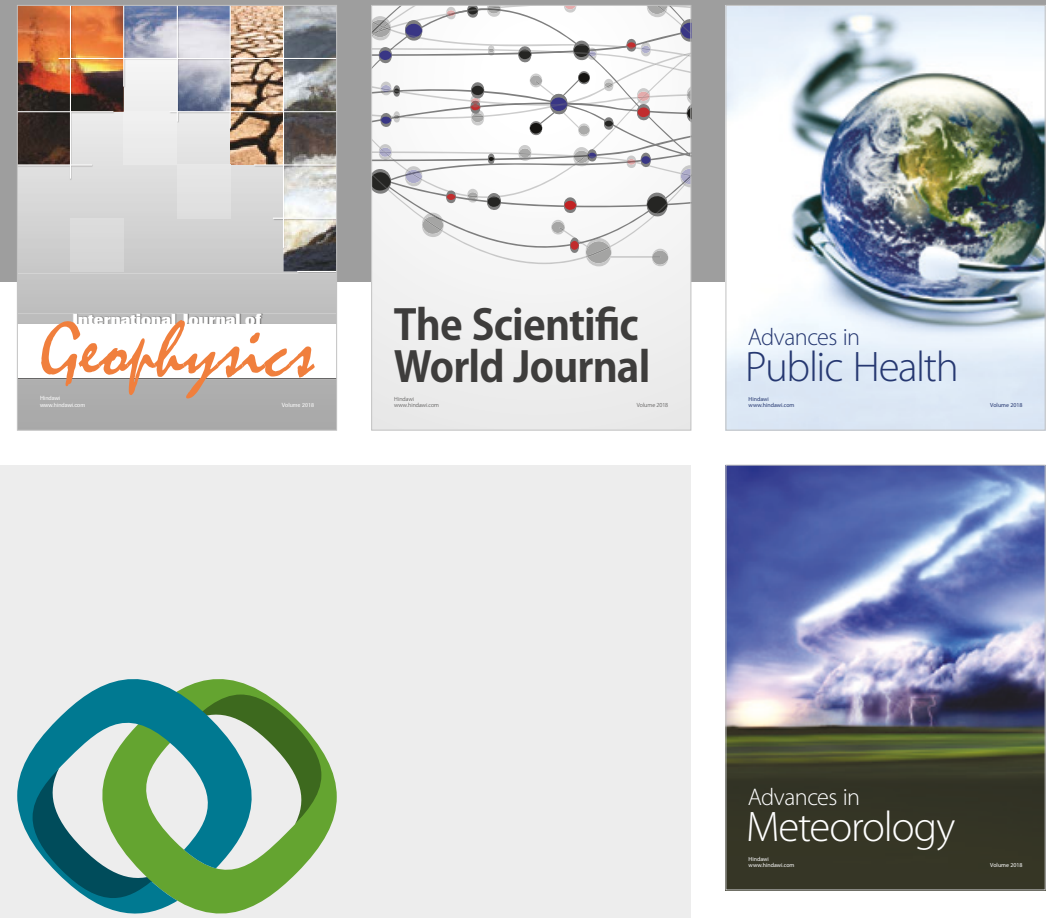

Advan

Public Health

\section{Hindawi}

Submit your manuscripts at

www.hindawi.com
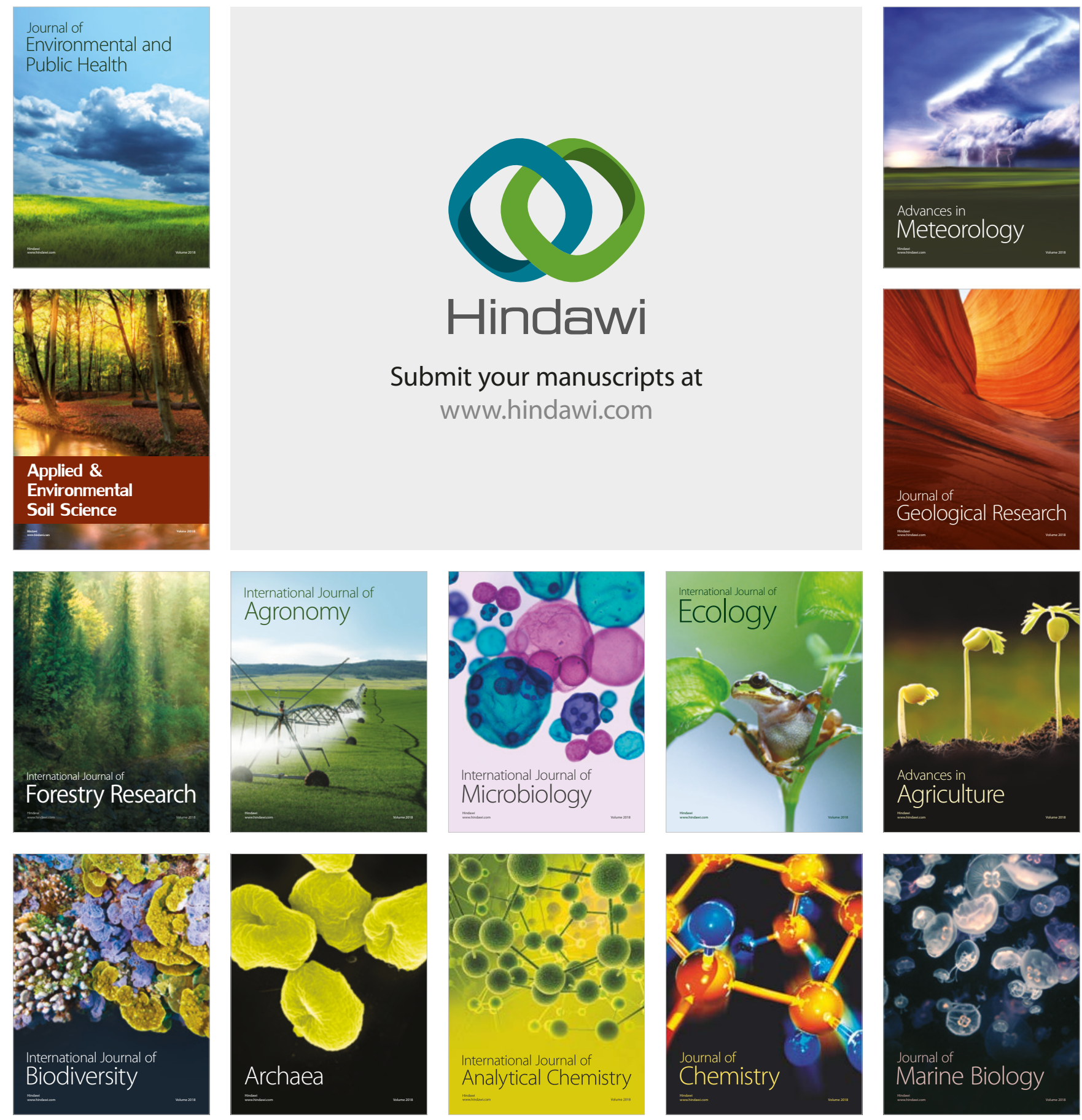